\title{
Chapter 13 \\ Fisheries and Socio-economic Change in the Thanlwin River Estuary in Mon and Kayin State, Myanmar
}

\author{
Cherry Aung
}

\subsection{Introduction}

The Thanlwin or 'Salween' River Estuary is well-known in Myanmar for its rich fishery and wide range of fishes. The daily flood and ebb tides bring fresh and sea water together to support a diversity of fresh, brackish, and marine fishes, creating dynamic and fertile spawning and feeding grounds. Local communities in Mon and Kayin States have depended on the estuarine fishery as part of their local economies for generations, but at present a variety of factors, including geo-hydrological changes, overfishing, and unsustainable and illegal fishing methods, have depleted the fishery. While local workers seek opportunities elsewhere, particularly in neighboring Thailand, domestic migrants from other parts of Myanmar have moved to find work in this precarious estuarine fishery. This has meant that the estuary has changed dramatically: not only ecologically, but also in terms of labor and the socio-economic status of its resident communities.

This chapter focuses on community fishery livelihoods in this estuary, exploring the transformation of riparian communities in Mon and Kayin State. The chapter proceeds with the understanding that the Thanlwin is a significant source of food and livelihoods for the approximately 6 million people who live in the basin in Myanmar, particularly those who rely on the Myanmar stretch of the river (Johnston et al. 2017). It is well known that poverty in Myanmar is geographically positioned; specifically, poverty is higher in rural coastal and mountainous areas, particularly for agriculturalists who rely on the "monsoon crop" (Ministry of Planning and Finance and World Bank 2017). Much less is known about the links between poverty, recent socio-economic change in Myanmar, and non-agrarian livelihoods such as fishing. The Myanmar Department of Fisheries reports that export earnings

Cherry Aung, Professor and Head of the Department of Marine Science, Pathein University; Email: missaungmarine@gmail.com.

(C) The Author(s) 2019

C. Middleton and V. Lamb (eds.), Knowing the Salween River: Resource Politics

of a Contested Transboundary River, The Anthropocene: Politik-Economics-

Society—Science 27, https://doi.org/10.1007/978-3-319-77440-4_13 
for fish were in the range of more than 500 million dollars in 2013-2014 alone, and these earnings are rising with increased demand (World Fish 2016). These assessments, however, do not account for the local value of fish for subsistence or the trends seen locally. As such, this chapter provides insight into the changing livelihoods of fishers in this estuarine context, and adds nuance and detail to the broader overviews of Myanmar's socio-economic change in recent years.

The research presented in this chapter was conducted through interviews, focus groups, and household surveys across four villages located in the estuary over the period of 2015-2016, and investigates changes to fishers and livelihoods over a ten-year period beginning in 2005. The author is familiar with the livelihoods of these villages from her long-time work as a marine scientist, and from personal experience living along the Thanlwin River.

The chapter first provides background information on the current governance and fisheries situation along the Thanlwin before discussing the methods used to conduct this research. Through the study of four fishing villages, the author presents evidence of fisheries decline and the associated overfishing and environmental changes that have impacted fish habitat and species in the estuary. The following section examines the socio-economic differentiation linked to fishing and other events in the estuary. The chapter concludes with recommendations for better management and further research.

\subsection{Background and Governance of the Lower Thanlwin}

The Thanlwin estuary is a complex ecosystem, but little is known about it, particularly outside of Myanmar. The estuary sees the mainstem of the river connect to four tributaries and supports a wide diversity of fishes. For local people in the inshore fisheries zones of the Thanlwin estuary, catching fish for personal consumption and for market is a part of daily life. Men usually fish on boats, which require time away from home, while women and older people (above 60) are involved in other aspects of fish production. This production work ranges from repairing nets and preparing fish products, to selling fish in the markets. A range of fresh, brackish, and marine fishes comprise the local inshore fishing economy.

Offshore fishing is a bit different. The offshore fisheries require larger boats, and greater investments in equipment. While most offshore fishing is commercial, some local residents work in the fishery as laborers, which requires going offshore for weeks, and sometimes months, at a time. Nga pone na (Paradise threadfin) and Nga pyat (Coitor croaker) are the important commercial fishes around the estuary, but these fishes as well as others detailed below are in decline. ${ }^{1}$

\footnotetext{
${ }^{1}$ The fish species names presented in this paper include both Myanmar language names and scientific names in parenthesis.
} 
Technically, the inshore fishery includes the regions between the low tide mark and ten nautical miles from the shoreline. The offshore fishery is beyond that point, and these distinctions have implications for management. The offshore fishery is managed by the national government, whereas the inshore fishery is the responsibility of the regional government (Soe 2008). At present, there are four laws related to fisheries in Myanmar that are relevant to both the inshore and offshore fisheries. This includes the inland fishery law, offshore fishery law, aquaculture law, and the foreign fishing investment law (Tsamenyi 2011).

While these four laws exist on the books, law enforcement is weak and some of the offshore fishing boats fish close to the shore (Tsamenyi 2011). This has created conflict between the small inshore fishing boats and the large offshore boats, with the smaller boats unable to compete with the larger boats. The small fishing boats do not have a way to address this problem, so many fishers involved in the inshore fishery either change their livelihoods or become workers on the larger boats.

In response to these issues and reported declines, the Ministry of Fisheries announced in February 2012 a seasonal fishing ban for three months from May 5 to end of July to prevent the declining of fish stocks in the river, and a corollary ban from June 1 to end of August for offshore fisheries. Moreover, protected areas for lobsters and fishes were marked. Using poison is not allowed. While these moves are significant, enforcement remains weak.

Related to these fishing practices and legal instruments, there is a need for research in addition to enforcement. As the director of the central Yangon Fisheries Department, U Tin Win Myint, told the Myanmar Times, "In our country, there is no research. We have poor conservation and recordkeeping. But now we're starting to take action" (Khin Wine Phyu Phyu, 7 July 2016).

While the author concurs that more research is needed, it is important to understand what kind of research needs to be conducted. For instance, how is the decline in fishing affecting riparian communities? Are they becoming increasingly connected to broader livelihood changes and external markets? Local livelihood strategies are not only changing in relation to fishing, but are increasingly driven by migration, remittances, and market opportunities. Social-economic change in the region is not entirely the result of decreased fish catch. Increasing mobility and strong external markets, both domestically and internationally, offer opportunities for higher wages than the local agricultural and fishing sectors, which has enticed many people to move. Many people in the estuary have moved or migrated to other places to work, especially to Thailand, but also Malaysia and Singapore. Poorer individuals who lack the means to travel or relocate for work remain in the region. They have not been able to invest in fishing equipment, which would allow them to compete with large scale fishers in more open water, and are thus facing increased livelihood vulnerability, inequality, and sometimes conflicts. This chapter highlights the interrelationships between these important changes in the Thanlwin estuary. The next section details how the author undertook the study. 


\subsection{Research Methods and Approach}

The research data presented in this chapter on livelihoods and fishery status and trends were collected through surveys. Approximately 60 households were surveyed. The household survey consisted of four sections: amount of fish catch (and decline), impacts, resilience/response, and policy interventions. The author also brings expertise as a marine biologist who has studied estuarine environments for more than 10 years, which includes familiarity with fish species identification, habits, and habitat requirements.

The author also conducted focus group discussions and key informant interviews. Each focus group included seven to ten people in total, inclusive of fishers, and also included household heads from different social groups. Key informant interviews with local government officials, and focus group discussions with farmers associations, village leaders, and local government officials were also carried out. The majority of research was conducted in 2015-2016, with some follow up visits in 2017.

The analysis of the data included assessing the impacts of the fish catch decline and the related decline in income and food security. Livelihood activities and changes were assessed through focus group interviews and participatory rural appraisal surveys using different tools, including a household questionnaire, with the objective of acquiring baseline data on fisheries and the socio-economy of the targeted villages. Adaptive measures taken by communities were also identified.

To understand the fishery status across the estuary, the author selected four fishing villages in the estuary (See Figure 13.1: Map showing the four study areas in the Thanlwin River Estuary). Each of the four villages are known as productive fishing communities and are situated on the banks of the four tributaries of the Thanlwin River Estuary.

These four villages are Kayar village (along the Gyine River), Kyone-sein village (along the Attran River), Kau-mu-pon village (along the Mawlamyine River, on Bilukyun island), and Khindan village (along the Dayebauk River). Kayar village is situated within Kayin State and the rest are within Mon State. For the scope of this paper, the author will not go into great detail on each of the four villages, but these four villages are generally small, with populations ranging from 900 residents (Khindan village) to approximately 3,000 residents (Kayar village). The predominant occupation, over the 10-year period from 2005 to 2015, was in the fisheries or in fishing-related work.

The following diagram, Figure 13.2: Diagram of Fisheries and Livelihood Changes, represents the trend of fisheries and related socio-economic change. This research is positioned within an overall approach which seeks to understand "how livelihoods shift, evolve and adapt in villages where numerous actors are vying for access to the same natural resources" (Marschke 2015: 5). This diagram shows the links between various facets of the study, particularly in how the decline in fish is linked to both habitat loss and broader socio-economic changes. 


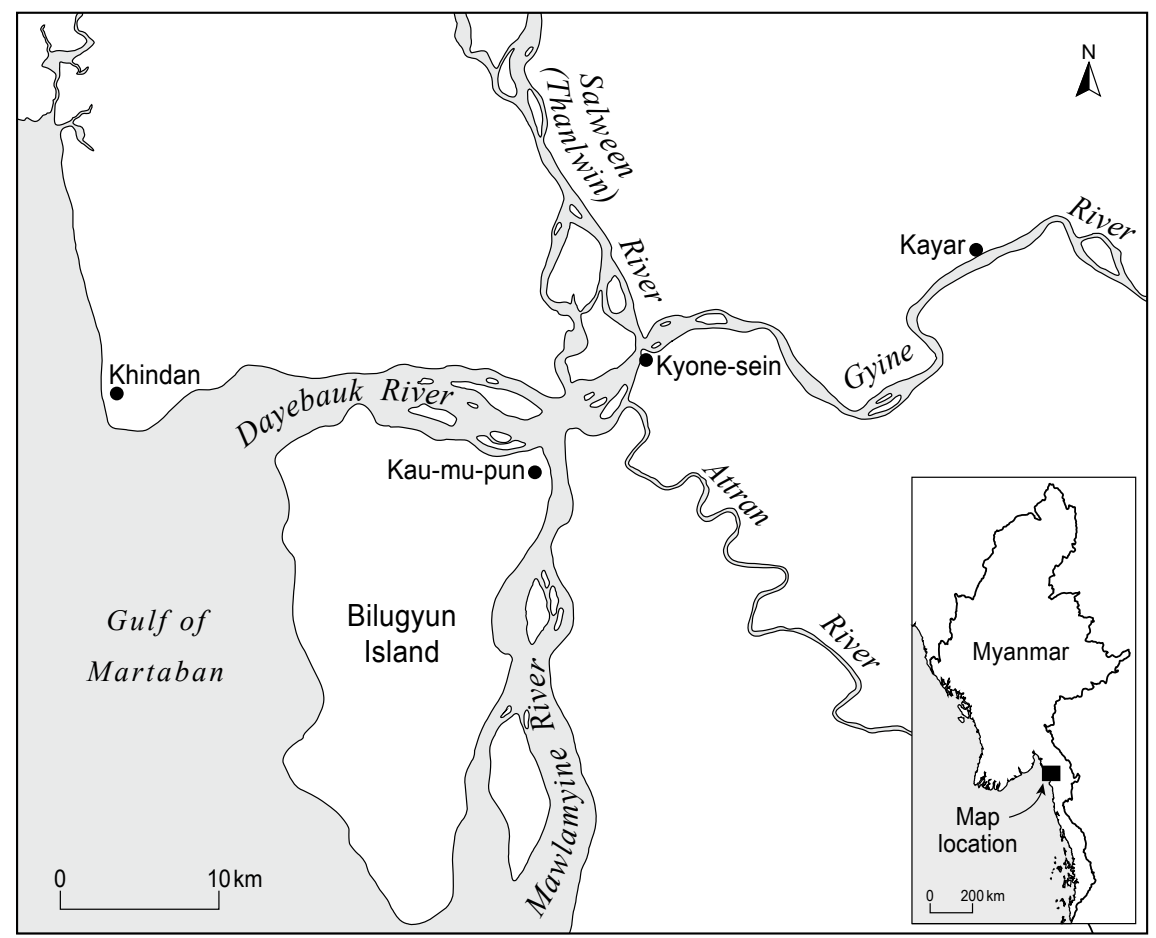

Fig. 13.1 Map showing the four study areas in the Thanlwin River Estuary. Source Cartography by Chandra Jayasuriya, University of Melbourne, with permission

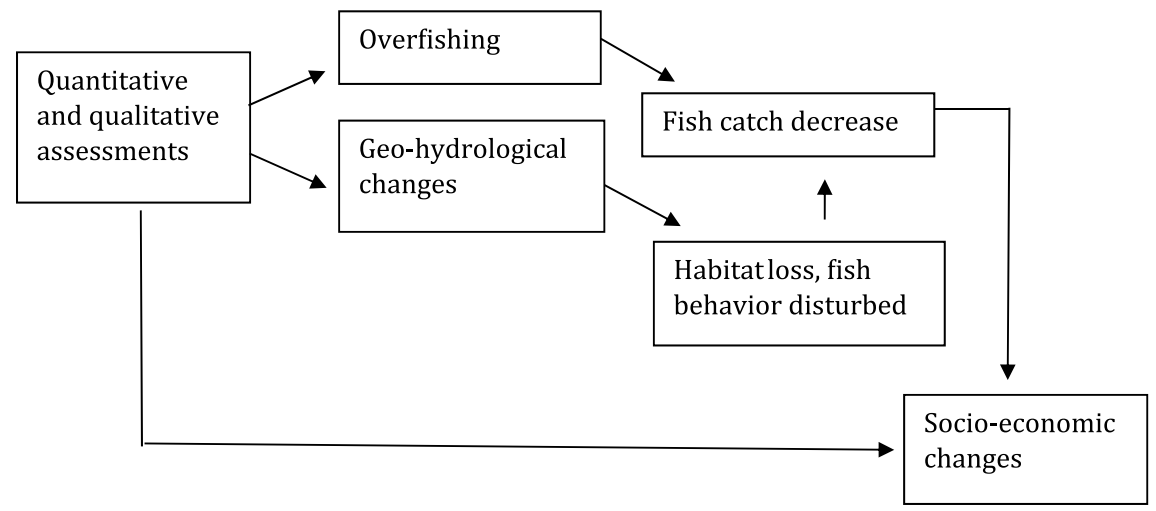

Fig. 13.2 Diagram of fisheries and livelihood changes. Source Created by Author 


\subsection{Estuary Region and Functions}

Before moving onto the findings of this study, it is essential to outline the ecological functions and change in the estuary in relation to fisheries. All four tributaries of the estuarine region discharge into the Andaman Sea via the Gulf of Martaban. The Attran and Gyine rivers are at the upper region of the estuary and provide a variety of fishes and other resources. The Mawlamyine and Dayebauk rivers are at the lower region of the estuary, and function to discharge fresh water from the Thanlwin, Gyine, and Attran rivers to the Andaman Sea via the Gulf of Martaban.

All four tributaries experience a daily ebb and flood tidal influence, with a variable range of tidal inundation depending on the distance from the sea. The salinity level is high at the mouth of the Mawlamyine and Dayebayk rivers (where the more coastal villages of Kau-mu-pon and Khindan are situated), while the salinity is lower in the middle of the Thanlwin River and where the four tributaries meet. The more inland rivers Gyine and Attran have low salinity and are almost entirely fresh at some times of the year. This is where Kayar and Kyano-Sein villages are located. It is well known that the place at the border of the saline water intrusion zone in Gyine River, which is very near Kayar village, is one of the best fishing areas and is an important part of this investigation.

It is also important to understand the seasonal variation within the estuary. Local people report catching a variety of fishes according to the season and the tides. Rates of salinity and seawater intrusion vary according to season, which affects fisheries. Seawater intrusion can extend up to about $60 \mathrm{~km}$ in the Gyine River, particularly during the dry season.

Different types of fishes thrive within this range of habitats. Fresh water fishes and prawns are plentiful at the inner region of the Gyine and Attran rivers, and also in the upstream region of the Thanlwin River, while marine and estuarine fishes enter along with seawater into the inner region. This gives the estuarine region its unique environment, maintaining a variety of marine, brackish, and fresh water fish types that support the livelihoods of millions of people living along the estuary.

The next section presents the main findings from the study related to declining fish catch as evidenced by a range of factors.

\subsection{Research Results: Fisheries Decline Evidenced by a Range of Indicators}

At present, local communities are facing the problem of a declining fish catch in the river, the estuary, and even in the sea. The diversity, average size, and average catch of fish is reported to be declining. The reason for this decline is a variety of anthropogenic and environmental stresses. Local fishermen from the inner river and estuarine region are also facing many problems related to conflicts in the fisheries sector, which are linked to a variety of factors within the estuary. 
Table 13.1 Fishery status of the estuarine region between the years of 2005-2016

\begin{tabular}{|c|c|c|}
\hline Village & Main source of income $(\%)$ & \\
\hline Kayar (Gyine River) & $\begin{array}{l}\text { Fishery- } 6 \% \\
\text { Paddy field and farm-5\% } \\
\text { Working abroad- } 70 \% \\
\text { Other small scale jobs- } 19 \%\end{array}$ & $\begin{array}{l}\text { Fishery- } 25 \% \\
\text { Paddy field and farm- } 30 \% \\
\text { Working abroad- } 40 \% \\
\text { Other small scale jobs- } 5 \%\end{array}$ \\
\hline Kyone-sein (Attran River) & $\begin{array}{l}\text { Fishery- } 25 \% \\
\text { Paddy field and farm-10\% } \\
\text { Working abroad-50\% } \\
\text { Other small scale jobs- } 14 \%\end{array}$ & $\begin{array}{l}\text { Fishery- } 60 \% \\
\text { Paddy field and farm- } 25 \% \\
\text { Working abroad- } 10 \% \\
\text { Other small scale jobs- } 5 \%\end{array}$ \\
\hline Kau-mu-pon (Mawlamyine River) & $\begin{array}{l}\text { Fishery- } 25 \% \\
\text { Paddy field and farm-10\% } \\
\text { Working abroad-30\% } \\
\text { Poultry-10\% } \\
\text { Other small scale jobs- } 25 \%\end{array}$ & $\begin{array}{l}\text { Fishery- } 60 \% \\
\text { Paddy field and farm- } 20 \% \\
\text { Working abroad- } 10 \% \\
\text { Poultry-5\% } \\
\text { Other small scale jobs-5\% }\end{array}$ \\
\hline Khindan (Dayebauk River) & $\begin{array}{l}\text { Fishery- } 60 \% \\
\text { Paddy field and farm-5\% } \\
\text { Working abroad- } 20 \% \\
\text { Other small scale jobs-15\% }\end{array}$ & $\begin{array}{l}\text { Fishery- } 80 \% \\
\text { Paddy field and farm-5\% } \\
\text { Working abroad-5\% } \\
\text { Other small scale jobs- } 10 \%\end{array}$ \\
\hline
\end{tabular}

Source Reported in interviews conducted by the author

The fisheries status of the estuary over the past 10-15 years is represented across the four villages in Tables 13.1 and 13.2 (see Table 13.1: Fishery status of estuarine region between the years of 2005-2016 and Table 13.2. Fishing boats, gear, and overall fish catch between the years of 2005-2016). Examining these data, we can see the decrease in fish catch and efforts by local fishers to address this issue. For instance, responses from Kayar village show evidence of decline. Of the four villages in this study, Kayar is the most inland. In the past, Kayar was well-known for its fishery and the opportunity for a high catch along the Gyine River. Fishers have fished here and sold fish locally and to the city of Mawlamyine for decades. However, within the past 10-15 years, the fishery sector in Kayar has dramatically declined. Interviewees reported a steep decline, with fishing now representing only $6 \%$ of their main source of income, down from a more substantial $25 \%$ previously. This lost income is largely made up from working abroad, which is discussed below.

Kayar village was chosen as a case study because of its fishery status and its importance for the livelihoods of people living along the river. It is a place with a rich seasonal catch, and a variety of fresh, brackish and marine fishes. Freshwater prawns, Nga kyin (Carp), Nga phar mar (Osteobrama feae), Nga okephar (Hemibogrus microphthalmus, a fresh water fish which migrates from upstream of the river) and other commercial fresh water fishes migrate from upstream. Interviewees explained that Nga okephar has been locally extinct for the last 5 years. Additionally, according to interviews, one of the locally important commercial marine fishes, Nga Thalauk (Herring), is almost extinct in the river and Arius (Giant catfish) is totally extinct locally. Nowadays, fishers in Kayar village 
Table 13.2 Fishing boats, gear, and overall fish catch between the years of 2005-2016

\begin{tabular}{|c|c|c|c|c|}
\hline \multirow[t]{2}{*}{ Village } & \multicolumn{2}{|c|}{ Fishing boats and gear used } & \multicolumn{2}{|l|}{ Catch/month } \\
\hline & $(2015-2016)$ & (Before 2005) & $(2015-2016)$ & (Before 2005) \\
\hline $\begin{array}{l}\text { Kayar (Gyine } \\
\text { River) }\end{array}$ & $\begin{array}{l}\text { Small boats } \\
20 \text { (cotton, plastic net) } \\
20 \text { (purse seine net) } \\
4 \text { (large bag nets) }\end{array}$ & $\begin{array}{l}\text { Small boats } \\
40 \text { (cotton net) } \\
30 \text { (purse seine net) } \\
2 \text { (large bag nets) }\end{array}$ & $\begin{array}{l}0-5 \text { Viss } \\
\text { (post monsoon) } \\
0-2 \text { Viss } \\
\text { (monsoon) }\end{array}$ & $\begin{array}{l}\text { 50-200 Viss } \\
\text { (post monsoon) } \\
5-30 \text { Viss } \\
\text { (monsoon) }\end{array}$ \\
\hline $\begin{array}{l}\text { Kyone-sein } \\
\text { (Attran River) }\end{array}$ & $\begin{array}{l}\text { Small boats } \\
100 \text { (cotton, plastic net) } \\
10 \text { (purse seine net) } \\
5 \text { (large bag nets) }\end{array}$ & $\begin{array}{l}\text { Small boats } \\
200 \text { (cotton net) } \\
40 \text { (purse seine net) }\end{array}$ & $\begin{array}{l}0-50 \text { Viss } \\
\text { (post monsoon) } \\
0-20 \text { Viss } \\
\text { (monsoon) }\end{array}$ & $\begin{array}{l}\begin{array}{l}200-500 \text { Viss } \\
\text { (post monsoon) } \\
30-150 \text { Viss } \\
\text { (monsoon) }\end{array} \\
\end{array}$ \\
\hline $\begin{array}{l}\text { Kau-mu-pon } \\
\text { (Mawlamyine } \\
\text { River) }\end{array}$ & $\begin{array}{l}\text { Large boats } \\
15 \text { (bag nets) } \\
\text { Small boats } \\
100 \text { (bag nets) }\end{array}$ & $\begin{array}{l}\text { Large boats } \\
60 \text { (bag nets) } \\
\text { Small boats } \\
160 \text { (bag nets) }\end{array}$ & $\begin{array}{l}0-50 \text { Viss } \\
\text { (post monsoon) } \\
0-20 \text { Viss } \\
\text { (monsoon) }\end{array}$ & $\begin{array}{l}\text { 200-500 Viss } \\
\text { (post monsoon) } \\
\text { 50-200 Viss } \\
\text { (monsoon) }\end{array}$ \\
\hline
\end{tabular}

Source The dates and data were provided by local people, and may not be precise. Viss is a Myanmar measurement unit of weight equal to $1.63293 \mathrm{~kg} / 3.6$ pounds

also face the problem that fresh water fishes rarely travel down from the upper region of the river, and brackish and marine fishes rarely travel up from the sea. It is hard to survive as a fishing family in Kayar.

Closer to the sea, in Khindan village, we see a similar decline in fish catch from 80 to $60 \%$ nowadays. The Darebauk River, where Khindan is located, is also well known as a highly productive fishery resource. About 37 species of marine and brackish fishes were observed by the author. The fishers here catch fishes from the river and also from the sea. Interviewees reported that over the past ten years, not only the local catch but also the broader fishery industry has declined. The economy of local residents and migrantswho depend on fisheries has therefore changed, with harmful consequences for people in this area.

Another way that fisheries decline was communicated is related to changes in fishing practices. As the fish catch declines in the river, people must catch fish outside of the river at coastal inshore or offshore locations. Offshore fishing requires more powerful boats, as noted above, which represents a much higher investment for fishing gear and labor, and more time. The fishermen stay out at sea for one or more months on the larger boats, and they bring the fish catch in by using smaller carrier boats. The large fishing boat owners have to employ many workers. Poorer people cannot invest the equipment, time, and labor required to catch fish offshore. This is particularly true in Kau-mu-pon village, located on Bilukyun island along the Mawlamyine River. Here, the author was told that fishermen "leave their boats 
and become workers on large boats or work on carrier boats" (Kau-mu-pon village Interview, 21 July 2017).

In addition to a shift in practices, the overall amount of fishing boats is also decreasing, with multiple smaller fishing operations sometimes consolidated into larger ones. Interviewees explained that there were many more boats before. For instance, in Khindan village, there used to be more than 20 small boats, and now only about 5 remain. Moreover, the author was informed that in the past there were 600 large boats, but now (see Table 13.1: Fishery status of the estuarine region between the years of 2005-2016) only 40 small boats and 5 large boats remain in the Darebauk River near Khindan village. Most of the present-day fishermen are considered "rich people" who can invest in the fishery. Nowadays, some former fisherman now work under wealthy fishermen. This is because of the decreasing fish stock in the fishing grounds around the villages. Fishers must go further out, sometimes into the sea (beyond the estuary) to find fish, and in doing so, they must also compete with the high investment, modern large boats. Consequently, the socio-economy of the local population has also changed as fishers attempt to adapt to the situation, as discussed below.

Moreover, this shift in Khindan village is associated with the kind of fishing gear used. This is also the case in Kyone-sein village. Fishers in both villages recognize the fishing area where the Gyine and Attran rivers meet the mainstem of the Thanlwin as a key fishing area. Local people from these two villages explained in interviews that the fish catch has decreased since more than 10 years ago, after construction of the Thanlwin Bridge; they also note that illegal fishing has increased. Today, fishers report using almost entirely bag nets from boats (big and small). This is a more intensive form of fishing than traditional methods in response to fish declines. The large bag nets ${ }^{2}$ are set up across the rivers or creeks; these nets are more like 'walls' that divert fish into traps, with much bycatch. Locals also report an increase in the illegal use of poison in the commercial fishery, causing high mortality in shrimps and creek fishes, which local residents rely on for subsistence. Illegal fishing by baby trawler and fishing in the spawning season at the inner region of the channels are also reported. Overall, according to interviews with the local community in these two areas, the major cause of depletion of fishes within the Gying and Attran rivers is overfishing due to these illegal practices. Consequently, most men have migrated outside the village for work as they cannot catch enough fish to feed their families.

In addition, key informant interviews highlighted that not only local fishers, but some of the private commercial fishing operators who own the large boats are also witnessing declines. They are still carrying out fishing operations, but are facing pressure to increase their catch, so they sometimes turn to illegal nets and net sizes (smaller mesh), the use of explosives and chemicals, fishing illegally in closed

\footnotetext{
${ }^{2}$ Bag nets are long (often several hundred meters), vertical 'nets' or 'walls' running at right angles to the shoreline; such nets are set up this way to interrupt fish as they swim and direct them into a series of traps.
} 
seasons, and fishing beyond limited areas. These fishing operators are increasingly rare in the region as the fish catch has further declined.

Both commercial and local fishers sell their fishes in markets or to fish traders. Today, the traders are mostly ex-fishermen who stopped fishing because it did not provide an adequate income. These ex-fishermen also have the option to travel abroad to work and generally now have what they describe as a good income. As discussed further below, this has meant that only some people, including old people and women, are left to work in the fishery and to sell fishes to traders. However, even the traders report less income than in the past as the fish trading intensity is decreasing. The fish trade still continues, mainly during the high season.

\subsubsection{But, Why? A Range of Reasons for Fisheries Decline}

Interviewees explained that there is a long list of reasons for the fishing decline in the sea and the river, including: over-exploitation, high/increased sedimentation rates, the effects of the Tsunami, and changes in water direction. They also identify the move to modern fishing techniques as a reason for changes in fishing productivity, as this requires high investment and is more labor intensive, and requires fishers to change their fishing grounds. Indeed, local livelihoods are threatened by many factors, and not all are apparent locally. For example, destruction of the seasonally flooded forest to expend agricultural land use generates conflicts between fishing, agriculture, and environment conservation (Blake and Pitakthepsombut 2006; Hortle and Suntornratana 2008; Khumsri et al. 2006). A recent study on the Upper Salween, also known as the $\mathrm{Nu}$ Jiang, argues that environmental degradation has resulted predominantly from human activities. The research shows evidence of environmental impacts on the upper stretches of the River from land use and land cover change, land-resource utilization and regional economic development (Feng et al. 2010). Geo-hydrological changes to the river, such as increased sedimentation, also play a role (see more below). Yet, in the lower Salween (Thanlwin), perhaps the most pressing issue is overfishing. Overfishing has increased due to the need to meet the rising demand for sustaining local households, and has become a dominant threat to fisheries and fish stocks in the estuary.

\subsubsection{Overfishing and a Changing Fishery}

Gradually, the fishes and fish products trade has shifted to the wider market in the region. As noted, wealthier people collect or buy the fishes from the fishermen and sell the fishes to nearby cities or abroad. Later, the traders provide funding for the fishers to buy fishing nets, boats and engines. In return, the local fishers are obliged to sell the fishes only to the traders who invested in their practice, and often end up 
selling their catch to the traders at a low price. This arrangement allows for those who do not have funds for financial investment in equipment to continue work in fishing. We see the fishery sector become 'modernized' by more intense fishing practices, using high power engines, larger boats, and modern gear like large bag nets. These nets, as noted above, result in bycatch, and are generally seen as destructive when left in the water for long periods of time, rather than at particular moments of fish migration or seasonal flow.

Accordingly, fisheries operations have intensified, and the fish catch has declined over the past ten to fifteen years. This in turn has further intensified fishing activities and has increased irresponsible fishing practices, moving them further offshore and to spawning times when fishing is banned. Also of note is over-exploitation by using large stationary gill nets and modern techniques outside the estuarine basin and the increase of offshore fishing boats. This is one of the reasons that brackish fish are declining in the area, even though there is a seasonal ban and permits are limited. Fishers report that the numbers of marine and brackish fishes entering to the inner estuary, and the Dayebauk and Mawlamyine tributaries, have become fewer.

The major causes of depletion of fishes within the Gyine and Attran rivers are similar; interviewees noted overfishing by using small mesh sized nets, illegal fishing using poison which causes high mortality in shrimps and creeks fishes, and illegal fishing by baby trawl and by fishing in spawning season in inner regions of the channels. Local people from along these two rivers explained in interviews that fish catches have declined since over 10 years ago, after construction of the Thanlwin Bridge.

As noted above, the inland fishery law falls under the authority of state governments, so the Thanlwin River Estuary is under the authority of the Mon and Kayin State Governments. The closed season is May-June in inland waters and June-August in offshore areas. Fishing is prohibited in inland waters during these months due to the spawning times of most of the fishes. In fact, only licensed fishing boats limited in number and size are permitted, and fishers must pay for these licenses. Yet, because enforcement is weak and Mon and Kayin are mixed authority areas, local people say that some areas of the estuary are also governed by local ethnic armies, such as areas of Mon and Kayin State where ethnic armed groups play a role in governance, particularly in the villages. In some situations, it was reported that due to weak law enforcement of fishing bans, ethnic armed groups played a role in patrolling these areas for illegal fishing, adding a further dimension to governance.

\subsubsection{Sedimentation and a Changing River}

While overexploitation and governance challenges are key reasons for fisheries decline, there are other important factors. There is evidence of extensive mudflat formation by the gradual erosion of some parts of the estuary. While this is 
providing an opportunity for some fishers (particularly in Khindan) to access mudflat fisheries and other mudflat commercial resources, overall these sedimentation changes mean that some of the behavior patterns of estuarine life, especially fishes, has also changed. Some of the good fishing grounds within the estuary are degraded, and some fish species have not been found for the last 10-15 years. Due to these changes, some marine and brackish fishes cannot enter the inner region of the rivers and some of the fresh water fishes from upstream are now lost, according to fishers. This may also be because some algae or other detritus has been depleted from the river bottom due to increased rates of sedimentation. These algae and detritus are the main food sources for most marine fishes, so their loss leads to fish decline. Also, some brackish fishes (like Herring or Helsa) do not thrive in the lower water levels that have resulted from the increase in sedimentation in recent years.

Some local people directly identified links between fish declines and increased sedimentation. One fisherman from Kau-mu-pon village explained, "The water level has become lower over the past 10 years due to high sediment buildup on the bottom of the river so the algae, which is food for some fishes, has decreased which causes a decrease in fishes" (21 July 2017).

Other fishermen from Kau-mu-pon village explained in focus group discussions that in their decades of fishing experience, "Some of the fish habitat loss and fish migration behavior change [is because] some fishes don't like the shallower water with more sediment" (21 July 2017). Many interviewees also linked this increased sedimentation to the Thanlwin Bridge construction more than 10 years ago.

However, as noted above, this story of fisheries decline does not end with the changing river ecosystem or changes in fishing techniques. These declines are linked to broader social-economic shifts, such as in/out migration and shifting dimensions of gender and labor, as discussed in the final section.

\subsubsection{Socio-economic Changes in the Village}

While many activities have contributed to the decreased fish catch within the estuary and surrounding regions, the declining fish catch has in turn contributed to dramatic changes in the livelihoods of fishers and migrants. The declining fish catch and increased competition with larger fishing boats has caused some fishers to quit fishing, and some have sold their fishing boats and equipment. Some now work for wealthy fishers who can afford to invest in high power fishing boats and costly permits. At the time of the interviews, most of the fishers who had left the trade explained that they had made their decision based on the high investments required and decreased incomes they were experiencing. Depending on each individual's situation, they changed their livelihoods to focus on other activities, such as gardening, farming and other businesses. Some people decided to go abroad to work, mainly in Malaysia, Thailand, and Singapore. Some migrant workers who moved to the estuary area are now returning to their hometowns in other parts of Myanmar. 
Some local people do continue fishing, mostly for local consumption, within the creeks and rivers by using traditional fishing methods like using baskets, as seen in Kayar village. However, the fish caught by local fishers are not enough for village consumption, and the village market now sells non-local fish from the Mawlamyine market.

In the villages nowadays, not only fishing families but also other families mainly depend on remittances from family members working abroad (see Table 13.1). It was reported that larger numbers of residents of each of the four villages are going to work outside the village, from $70 \%$ in Kayar village, which is closest to the Thailand border, to $50 \%$ in Kyone-sein, and less in Kau-mu-pon and Khindan villages, at $30 \%$ and $20 \%$ respectively. Thus, with only a portion of the total village population remaining in the village year-round, the situation in the village has changed. The population now consists of mostly young children, who stay for education, and elderly people, who still work in the small-scale fisheries or do gardening. Villagers who used to farm in the paddy and groundnut (peanut) fields, and workers cultivating palm sugar, have mostly left these livelihoods. A visit to the estuary reveals that most of the fields around the villages are no longer used for agriculture, except for vegetable gardens planted by elderly people for local consumption.

There is also a gender dimension to the changes in age composition of these villages. At least two shifts are observable. While both men and women migrate out of the village for work, it is more common for men to migrate. Also, household labor roles have shifted even for those families who remain in the village.

When the fish catch was more plentiful, the role of men in the villages included fishing, trading, working in fish processing like pounded fish and prawn, and making salty and dry fishes. The women largely prepared and mended fishing nets, made fish and prawn paste, salted fish, dried fish, and sold fish and fish products. However, as noted, at present many men have quit fishing. Those still involved are not doing it on a family scale, but are fishing for sale to traders or are employed as workers on larger fishing operations. As a result, many of the women in the village are now without jobs. When asked about the declining fish catch, one fisherman from Kau-mu-pon village explained, "Work in the offshore fishing industry is mostly for men. Women who used to work in the local fisheries have had to change jobs because of the declining fisheries" (Interview, 21 July 2017).

With the decline in fishing and the shift to fishing for sale and export, local communities do not have enough fishes for daily consumption. As a result, aquaculture fishes from other places are imported and women from fishing families have found work selling them instead of fishes from local rivers.

Moreover, this shift is not the same in each village. In Khindan, fishing families have focused on specific products for export at a high price to China. These high priced products include fresh water shrimps, the swim bladder of fishes, and eggs of particular fishes. In this case, the women work in preparing these special fish products for export. By contrast, in Kayar village there has been a switch to traditional fishing methods, focusing on smaller creeks. 


\subsection{Discussion and Conclusion: How to Make Sense of a Transforming Estuary?}

In the author's assessment, overexploitation is a main cause of declining fisheries due to high demand and weak law enforcement. As fishing efforts increase and intensify, there are also growing problems concerning illegal fishing and, as a consequence, fishers are pushed out of the fishing profession. This decline in fishing as a livelihood has impacted the living conditions of both young and old, and men and women in communities along the Thanlwin Estuary.

The diagram introduced earlier (Figure 13.2: Diagram of Fisheries and Livelihood Changes) represents some of the relationships between fisheries trends and socio-economic changes, particularly how the decline in fish is linked to both river changes (like habitat loss) and broader socio-economic changes.

Results shown here indicate that some fishing communities are concerned about their economic situation due to the declining fish catch. Projected socio-economic trends are normally dependent on the income perspectives for individuals and households (e.g. Ministry of Planning and Finance and World Bank 2017). Also, in this case, the combined effect of declining fisheries and decreasing income has caused a significant proportion of the local people to move abroad for work.

Here, the combined effects of fish declining and increasing incomes have caused a significant proportion of the local population of workers to move abroad. At the same time, the inland and near shore fisheries are worth a lot to subsistence communities, even if not in terms of income. This is especially true for the rural riparian populace due to the low investment required in local fisheries, and the historically high yield, which plays an important role in local food security.

In this area, both the regional and national government have tried to manage the illegal inland and costal marine fisheries through various means such as imposing a seasonal ban on fishing. But there is much more to do. The inner estuary is under the fresh water fishery law, which is governed by the regional government. The law should focus on illegal fishing methods such as the use of poison, catching spawning fishes in the off season, illegal fishing by using large gear and nets along the rivers, and the use of bottom trawlers. The outer estuary is under the marine fishery law, overseen by the national government. It should be well managed with a focus on the very evident illegal fishing and illegal gear use.

Of course, there is work to do beyond management, patrolling, and policy efforts. The local government should improve research capacity on fish behavior and estuarine processes. This relates to the need to reduce high sedimentation rates and problems along the rivers and the channels to improve fish production and to predict any disturbances in the estuary. Cooperation between the local government and communities with the national research institutions is highly recommended, including collaboration with regional and international research partners. Further research is also needed to integrate knowledge on fisheries changes with broader livelihoods and socio-economic impacts in order to find solutions to these pressing issues (see also, Swuam Pyaye Aye Aung et al. 2016). 
In sum, like many rivers in the world, the Thanlwin River Estuary is facing pressures from a number of ecological and anthropogenic stressors. In Myanmar, while poverty levels are high, projections show improvements, as seen by the assessment referred to in the introduction to this paper, prepared by the World Bank and the Ministry of Planning and Finance (as noted above, see also: World Bank 2017). Yet, this chapter shows that there remains much work to do to understand how these trends impact different people in Myanmar. It also shows how changes in fisheries affect the rural poor unequally, and how these changes are related to a range of ecological and socio-economic factors.

\section{References}

Blake, D., \& Pitakthepsombut, R. (2006). Situation analysis: Lower Songkhram River Basin, Thailand. Bangkok: Mekong Wetlands Biodiversity Conservation and Sustainable Use Programme. Retrieved from: https://portals.iucn.org/library/node/8842.

Feng, Y., He, D., \& Li, Y. (2010). Ecological changes and the drivers in the Nu River basin (upper Salween). Water International, 35(6), 786-799.

Hortle, K.G., \& Suntornratana, U. (2008). Socio-economics of the fisheries of the lower Songkhram River Basin, northeast Thailand (No. 17). Vientiane, Lao PDR: MRC.

IUCN (International Union for Conservation of Nature). (2013). Ecological survey of the Mekong River between Louangphabang and Vientiane Cities, Lao PDR 2011-2012. Vientiane, Lao PDR: IUCN.

Johnston, R., McCartney, M., Liu, S., Ketelsen, T., Taylker, L., Vinh, M.K., Ko Ko Gyi, M., \& Aung Khin, T., Ma Ma Gyi, K. (2017). State of knowledge: River health in the Salween. Vientiane, Lao PDR: CGIAR Research Program on Water, Land and Ecosystems. Retrieved from: http://hdl.handle.net/10568/82969.

Khin Wine Phyu Phyu. (2016, July 7). Enforcement of fishing ban? It's complicated. Myanmar Times. Retrieved from: https://www.mmtimes.com/national-news/yangon/21261-enforcementof-fishing-ban-it-s-complicated.html.

Khumsri, M., Sriputnibondh, N., \& Thongpun, W. (2006). Fisheries co-management in Lower Songkhram River Basin: Problems and challenges. In MRC Conference Series (Vol. 6, pp. 121-126). Vientiane, Lao PDR: Mekong River Commission.

Marschke, M. (2015). Life, fish and mangroves: Resource governance in coastal Cambodia. Canada: University of Ottawa Press/Les Presses de l'Université d'Ottawa.

Ministry of Planning and Finance and World Bank. (2017). An analysis of poverty in Myanmar (Part 2). Myanmar: World Bank. Retrieved from: http://documents.worldbank.org/curated/en/ 829581512375610375/An-analysis-of-poverty-in-Myanmar.

Mya Than Tun. (2001). Marine fishes of Myanmar (Pelagic and Demersal). Yangon, Myanmar: Marine Fisheries Resources Survey Unit, Department of Fisheries.

Nelson, J.S. (1976). Fishes of the world. New York, NY: Wiley Inter Science.

Pratchett, M.S., Bay, L.K., Gehrke, P.C., Koehn, J.D., Osborne, K., Pressey, R.L., \& Wachenfeld, D. (2011). Contribution of climate change to degradation and loss of critical fish habitats in Australian marine and freshwater environments. Marine and Freshwater Research, 62(9), $1062-1081$.

Soe, K.M. (2008). Trends of development of Myanmar fisheries: With references to Japanese experiences. No. 433. Institute of Developing Economies.

Swuam Pyaye Aye Aung, Hitke Htike, \& Cauwenbergh, N. (2016, November 12). Evaluation of Mangrove Ecosystem Services in the Ayeyarwady Delta: A Step Towards Integrated Coastal Zone Management in Myanmar. Conference Paper for the International Conference on the 
Mekong, Salween and Red Rivers: Sharing Knowledge and Perspectives Across Borders, Faculty of Political Science, Chulalongkorn University, Thailand. Retrieved from: https:// static1.squarespace.com/static/575fb39762cd94c2d69dc556/t/5932f4b859cc6806cf1f5600/ 1496511675842/No.29_P700_712_Swuam+Pyaye+Aye+Aung.pdf.

Tint Hlaing. (1971). A classified list of fishes of Burma classification after Leo. S. Bery, 1949; Union of Burma. Journal of Life Science, 4, 507-528.

Tsamenyi, M. (2011). A review of Myanmar fisheries legislation, with particular reference to freshwater fisheries legislation. Environmental sustainable food security programme. Rome, Italy: FAO.

World Fish. (2016). Myanmar fisheries: Overview. Retrieved from: http://pubs.iclarm.net/ resource_centre/MFP-01-Overview.pdf.

Yin Yin Than. (2009). Fish capture in relation to the types of fishing gear in some townships of Yangon Division. (Zoology Department, Yangon University, Unpublished doctoral dissertation).

Open Access This chapter is licensed under the terms of the Creative Commons Attribution 4.0 International License (http://creativecommons.org/licenses/by/4.0/), which permits use, sharing, adaptation, distribution and reproduction in any medium or format, as long as you give appropriate credit to the original author(s) and the source, provide a link to the Creative Commons license and indicate if changes were made.

The images or other third party material in this chapter are included in the chapter's Creative Commons license, unless indicated otherwise in a credit line to the material. If material is not included in the chapter's Creative Commons license and your intended use is not permitted by statutory regulation or exceeds the permitted use, you will need to obtain permission directly from the copyright holder.

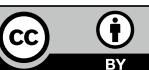

